Imlak Shaikh*

JEL Classification G11, G14, G15

Preliminary statement

\title{
THE BREXIT AND INVESTORS' FEAR
}

This paper investigates most important implied volatility indices of Eurozone, Asia-Pacific, Africa, Canada and USA on the event of Brexit election of UK. Since the international economic events signal new information to market participants, the Brexit event has gauged in the 12 global markets' volatility indices such as VFTSE, VIX, VDAX, VSMI, VSTOXX, VXJ, VHSI, VKOSPI, NVIX, VASX, VXIC and SAVI. A high fear of index about 20-36\% has been noticed on the day of Brexit decision. Abnormal returns and cumulative abnormal returns on volatility index are found to be positive, while majority of global equity markets have reported negative stock returns on this event. To investigate the 'fear-and-greed' of investors on this historical event, a window of 11 -day has been considered. The findings suggest that investors' degree of over-reaction on Brexit decision was very disappointing and fueled concerns on the future investment and portfolio choices. The key volatility indices were on the rise prior to the decision, while the market noticed astray and breached its normal range on the day of Brexit referendum. The findings suggest that market participants have diverted their funds into other safer investment outlets due to Brexit effects.

Key words: Brexit; Stock returns; Abnormal returns; Cumulative abnormal returns; Implied volatility

* I. Shaikh, Ph. D., Assistant Professor, Management Development Institute Gurgaon, Haryana, India (E-mail: imlak.shaikh@mdi.ac.in).

The paper was received on December $18^{\text {th }}$, 2017. It was accepted for publication on April $5^{\text {th }}$, 2018. 


\section{Introduction}

In the financial economics literature, several studies indicate that economic shocks such as global financial crisis, commodity price shocks and information technology bubble have significant effects on regional and national capital markets indices. A close look at the global financial markets performance and a careful attention to recent global security issues such as terrorism attacks exert several contradicting market behaviors. However, although some scholars analyze crossborder capital movements and stock markets indices around historical market information (e.g. Hamao et al., 1990; Äijö, 2008 and Wagner \& Szimayer, 2004), there is a dearth of research on the new market information events such as terrorism attacks and regional breakups. The paper, therefore, fills this important knowledge gap and contributes to economic events literature by analyzing the behavior of global equity market on the historical Brexit announcement.

In the quest of examination of equity market, 12 prominent implied volatility indices (i.e. VIX the trademark of CBOE) across the world stock markets are considered. While the Brexit negotiation started investors' excitement about the portfolio management has increased. The global equity market has lost approximately US\$2-3 trillion stock value due to the Brexit decision of UK. The implied volatility is the investors' fear and excitement index and stock markets' volatility expectation for the next 30 calendar days e.g. see Shaikh \& Padhi $(2015,2016)$. Due to Brexit decision on Friday 24, 2016, the expected stock market volatility closed globally between 20 $36 \%$. The FTSE market reported VFTSE about $26 \%$ and Eurozone STOXX volatility VSTOXX reached at $36 \%$. The high level of VIX as reported on Brexit day indicates the high degrees of market turmoil, and greater fear among the market players. The market players have started to reorganize their stock portfolio and buying safer and volatility products to hedge market position. Indeed, a great amount of distress is more likely to happen between UK and EU on this Brexit decision. The contagion effects can be observed for the next few years in terms of trading, investment, national income, economic development and politics.

Oehler et al. (2017) explore the impact of Brexit on stock price and firms' internationalization. The abnormal and cumulative abnormal returns have been calculated followed by the Brexit referendum. They find significant Brexit impact on the stock prices with firm of high domestic sales and confirm the market efficiency hypothesis.

Smales (2016) perform a case study on financial market uncertainty and Brexit announcement, and the relationship found to be positive and well defined. The implied volatility in UK and German financial market shows positive response to such uncertainty. The investors started re-evaluation of their market presence by taking new positions and trading aggressively in the options market. 
Tielmann and Schiereck (2017) examine the logistic companies as a result of announcement of Brexit referendum. Their argument is about the strong effects of Brexit on valuation of logistic companies. They have analyzed 107 logistic companies and results indicate negative value effect.

Brexit (2016) the report presented by Centre for Economic Performance, London School of Economics and Political Science highlight the plausible consequences of Brexit. The comprehensive report explains about Brexit and its impact on UK trade, UK FDI, immigration, income group and long-term impact on the fundamental of the UK economy.

Fernandes (2016) studies the impact of Brexit on UK deposit balances. The study administered on Monetary Financial Institutions (MFI's) deposits in asymmetric volatility framework. The work estimates around 5\% declines expected out of the Brexit event on the sight deposits (MFI Balance sheet). In additions, there has been significant increase of $16.95 \%$ in the time deposits.

Miller (2016) explain the possible consequences to be faced and resolved after the Brexit in the draft "Brexit impact across policy areas" published by House of Commons Library and Devolved Research Services. The overall Brexit economic impact highlighted in terms of international trade, FDI, overseas investors and effect of immigration on labor markets.

Äijö(2008) examines the stock market integration in terms of implied volatility index (VDAX, VSMI \& VSTOXX). The study concluded that the terms structure of implied volatility of these markets is highly correlated. On the information content of implied volatility as the forecast of future stock market volatility, it is confirmed that implied volatility outperforms the historical return volatility (inter alia, e.g. Christensen, \& Prabhala, 1998; Fleming et al., 1995; Blair et al., 2001; Hansen, 2001; Giot, 2005). Whaley $(2000,2008)$ calculated the implied volatility for the OEX option market and first time reported the VIX as the volatility index and named 'investors' fear gauge index', because investors are risk averse. Recently, Shaikh (2018) also confirms that VIX is the gauge of investors' concerns in the emerging markets. The information contained in the important announcement and its impact on the investors' fear well documented in the studies of Nikkinenand \& Sahlström (2001, 2004), Kearney and Lombra (2004), Chen \& Clements (2007), Antonakakis et al., (2013) and also report that decline in the stock returns triggers the high level of implied volatility. There are some of the important attempt such as Barbić \& CondićJurki (2017) and Dedi \& Škorjanec (2017) explains the effects of fiscal variable on equity market and models the stock market volatility for the EU markets. But, there is a lack of studies that document the behavior of global equity market on Brexit event. 
The rest of the work has been organized as section 2 offers the data and empirical model, section 3 reports the summary statistics and important results on Brexit and section 4 concludes the paper.

\section{Data description and empirical model}

\subsection{Data sources and description}

To examine the impact of Brexit referendum the data has been collected on volatility indices across the global stock markets. The data consist of 12 prominent markets namely US, UK, Switzerland, Germany, Eurozone, China, India, Japan, Korea, Australia, Canada and Africa. The frequency of the dataset sampled is daily and ranging from January, 2015 to July, 2016. By convention 240-260 trading days are included in the estimation window. There is a strong negative correlation between volatility and stock returns; hence the respective stock indices are downloaded for all volatility indices. The volatility indices of the individual countries are comprising of observed options prices written on the underlying stock index. The Brexit event 'UK exit of EU' announced on $24^{\text {th }}$ June 2016. The global stock market response to the Brexit depicted graphically (see, Fig.A1 and A2). Fig. A1 is the time series plot of AR and CAR for the event window; it is clearly visible that AR and CAR appears on the positive panel of the graph. This implies that Brexit created an ambiguity among the market participant through the event window $[-5,0,+5]$. Fig. A2 shows the times series plot of returns associated with underlying stock index and volatility index for the sample period May-July 2016. The close observation clearly indicates that throughout the sample period the market was trading in the positive volatility region. The impact of Brexit on US market has shown negative response, the fear returns was about $8 \%$. The rest of the stock markets such as Japan, China and Korea have reported investors' nervousness with positive volatility returns respectively $13 \%, 11 \%$, and $15 \%$. By close observation of Fig.A2, one can notice that Eurozone has shown high degrees of returns variability from May-July 2016. Moreover, the overreaction of the investors on negative stock returns is high as compared to positive stock returns. 


\subsection{Empirical model}

To document the impact of Brexit event across the global equity markets an event study methodology has been employed. The event study requires event window and estimation window. To account for the investors' behavior on the Brexit the event window for 11-day i.e. $[-5,0,+5]$ has been considered. The estimation window ranges from 240-260 trading days for the sample period. The log-transformed percentage returns have been calculated as,

Stock index returns

$$
R_{t_{m}}=\ln \left(\frac{P_{t}}{P_{t-1}}\right) * 100
$$

and, returns on volatility index

$$
r_{t_{v i x}}=\ln \left(\frac{V I X_{t}}{V I X_{t-1}}\right) * 100
$$

The study examines the investors' sentiment gauged in the fear index (e.g. Whaley, 2008) due to Brexit event. Consequently, the normal and abnormal returns are being calculated as,

Normal returns on volatility index $=N\left(r_{t_{v i x}}\right)$

and , the expected returns on the volatility index is estimated via its underlying stock index (see e.g. Fleming et al. 1995).

$$
E\left(r_{t_{v i x}}\right)=\hat{\varphi}_{0}+\hat{\varphi}_{1} R_{t_{m}}
$$

$\therefore$ Abnormal Returns

$$
\begin{aligned}
A R V I X & =N\left(r_{t_{v i x}}\right)-E\left(r_{t_{v i x}}\right) \\
& =r_{t_{v i x}}-\left\{\hat{\varphi}_{0}+\hat{\varphi}_{1} R_{t_{m}}\right\}
\end{aligned}
$$

The abnormal returns (ARVIX) and cumulative abnormal returns (CARVIX) have been calculated for the event window $[-5,0,+5]$. 


\subsection{Fixed effects panel regression}

In order to analyze the impact of Brexit on global equity market a panel dataset has been prepared with countries as cross section units and Brexit event window as time. The panel dataset consists of variables namely: abnormal returns, cumulative abnormal returns, volatility index returns and stock index returns. There are 11 data points $[-5,0,+5]$ and measured for 12 prominent countries with the respective volatility indices and stock indices. The general model $t=-5,-4$, $-3,-2,-1,0,+1,+2,+3,+4,+5, i=1,2 \ldots . .12$ (countries) expressed as follows:

$$
y_{i t}=\propto+X_{i t}^{\prime} \beta+u_{i t}
$$

Where $\mathrm{i}=$ denotes the countries

$\mathrm{t}=$ denotes the time (Event window)

$\alpha=$ scalar metrics

$\beta=\mathrm{k} \times 1$ metrics

$\dot{x}_{i t}^{\prime}=\mathrm{i}^{\text {th }}$ number on $k$ regressors (Here, stock index returns)

The one-way error component expressed as $u_{i t}=\mu_{i}+v_{i t}$. Here, $\mu_{i}$ is fixed and constant to be estimated, and $v_{i t} \sim \operatorname{IID}\left(0, \sigma_{v}^{2}\right)$. The study examines the Brexit effects on abnormal and cumulative abnormal returns based on fixed effects (time and cross section). To estimate the constants GLS method has been employed and controlled for fixed effect.

\subsection{Model description and hypothesis}

Under rational expectation and market efficiency the option prices impound important market wide information. The Brexit event is one of the well scheduled political events of EU's 28-member countries started early February of 2016 and concluded on 24 June 2016. The implied volatility is the market expectation for the future stock market volatility (e.g. Giot, 2005; Whaley, 2008 and Shaikh and Padhi, 2015). The expected stock market volatility rises significantly before the event and goes normal after the scheduled event become publicly available (e.g. Nikkinen and Sahlström, 2004). Below are some of the important hypotheses to be tested on the Brexit event connected with the investors' fear and excitement index.

(i) On Brexit, returns on the implied volatility index (stock index) should be positive (negative): if implied volatility is the gauge of investors' fear on 
the uncertain events to occur then the returns associated with such event should be reported negative. Hence, pre-event and on the day of Brexit decision returns on volatility index should be positive.

(ii) AR and CAR should be positive: if the market regard the Brexit event then around the event window $[-5,0,+5]$ the values of ARVIX and CARVIX should be positive and statistically significant.

(iii) If Brexit contain important market wide information then the estimates on ARVIX and CARVIX should spear positive and significant. The stock index returns shows an asymmetric (e.g. volatility feedback and leverage effects, French et al., 1987; Campbell \& Hentschel, 1992; Black, 1976; Christie, 1982) impact on the expected stock market volatility, hence in panel data regression the slope of stock index returns should be calculated positive and statistically significant.

The model used in the present study employs simple capital asset pricing model approach. The econometric framework considers only bench market returns of the respective volatility index. Perhaps, there can be other possible factors that may determine the expected level of implied volatility. The study also does not control for other macroeconomic events took place during this sample period.

\section{Empirical results and discussion}

\subsection{Descriptive statistics}

Table 1 summarizes the descriptive statistics on conventional returns around the event window $[-5,0,+5]$. Starting with the mean, in majority of the cases returns on stock indices and implied volatility indices appear to be reverse sign. If Brexit hold some forward-looking information then stock returns should be negative and volatility returns should be positive, the results are quit in line with the stated hypothesis. The hypothesis is also valid for the AR and CAR, reported on an average positive for all stock markets. The origin of the Brexit event is Britain; hence the market players of FTSE have al ready conceived the consequences of Brexit in their portfolio selection. The fact is clearly evident from the summary statistics reported for the UK equity market. In most of the condition the mean volatility returns appears to be less than the median, which signifies that returns' distribution is left skewed. It can be seen that skewness and kurtosis of stock returns and abnormal and cumulative abnormal returns are deviating from the normal values. The distribution of abnormal returns looks to be leptokurtic ( 7 markets out of 12). 
Table 1.

\section{DESCRIPTIVE STATISTICS ON THE BREXIT EVENT}

\begin{tabular}{|c|c|c|c|c|c|c|c|c|c|c|}
\hline \multicolumn{6}{|c|}{ US:SPX-VIX[-5,0,5] } & \multicolumn{5}{|c|}{ UK:FTSE-VFTSE[-5,0,5] } \\
\hline $\mathrm{DS}$ & rspx & rvix & ervix & $\mathrm{AR}$ & CAR & Iftse & rvftse & erftse & $\mathrm{AR}$ & CAR \\
\hline Mean & -0.0757 & .9982 & 0.4759 & 1.5223 & 13.5173 & -0.7268 & 3.6498 & 4.3006 & -0.6508 & -4.2398 \\
\hline Median & -0.2708 & 5.6594 & 1.8852 & -0.1904 & 15.3507 & -1.1237 & 7.1472 & 6.6267 & -1.6354 & -3.9272 \\
\hline Sk & 1.26 & -1.37 & -1.26 & 0.33 & 0.33 & 0.66 & -0.32 & -0.66 & 1.98 & 0.03 \\
\hline $\mathrm{Ku}$ & 1.51 & 2.73 & 1.51 & 0.08 & -0.89 & -0.47 & -0.87 & -0.47 & 5.47 & -0.87 \\
\hline \multicolumn{6}{|c|}{ Swiss:SMI-VSMI-5,0,5] } & \multicolumn{5}{|c|}{ German:DAX-VDAX $[-5,0,5]$} \\
\hline DS & rsmi & $\mathrm{mi}$ & smi & $\mathrm{AR}$ & CAR & $\operatorname{rdax}$ & rvdax & erdax & $\mathrm{AR}$ & CAR \\
\hline Mean & -0.3956 & 4.4152 & 1.9138 & 2.5014 & 35.2037 & -0.0731 & 2.9856 & 0.1979 & 7877 & 15.6560 \\
\hline Median & -0.5149 & 5.6482 & 2.4627 & 1.8370 & 32.1242 & -0.7031 & .0404 & 1.5727 & .3784 & 9.9590 \\
\hline Sk & 0.90 & 0.01 & .90 & 0.29 & 0.14 & 1.74 & 1.40 & -1.74 & 0.99 & 0.06 \\
\hline $\mathrm{Ku}$ & -0.77 & 1.54 & -0.77 & 0.20 & 1.56 & -3.37 & -0.48 & -3.37 & -0.32 & 1.90 \\
\hline \multicolumn{6}{|c|}{ Eurozone:STOXX-VSTOXX $[-5,0,5]$} & \multicolumn{5}{|c|}{ China:HIS-VHSI[-5,0,5] } \\
\hline $\mathrm{DS}$ & rstoxx & rvstoxx & ervstoxx & $\mathrm{AR}$ & CAR & rhsi & rvhsi & ervhsi & $\mathrm{AR}$ & CAR \\
\hline Mean & 019 & 393 & 0.5907 & 1485 & 3.9324 & -0.2581 & 481 & 1.4406 & 0076 & .6131 \\
\hline Median & -1.0539 & 4.8001 & 4.2132 & 2.7189 & 22.1060 & -0.6110 & 2.0809 & 2.8899 & .5778 & 3.2186 \\
\hline $\mathrm{Sk}$ & 1.77 & -0.78 & -1.77 & 0.97 & 0.17 & 1.27 & -0.55 & -1.27 & 1.07 & 0.66 \\
\hline $\mathrm{Ku}$ & -4.07 & -0 & -4.07 & 10 & 1.87 & -1.40 & -1.35 & -1.40 & -0.92 & 50 \\
\hline \multicolumn{6}{|c|}{ India:Nifty-NVIX $[-5,0,5]$} & \multicolumn{5}{|c|}{ Japan:Nikkie-VXJ[-5,0,5] } \\
\hline DS & rnifty & rnvix & ivix & $\mathrm{AR}$ & CAR & rnikkie & rvxi & ervxi & $\mathrm{AR}$ & CAR \\
\hline Mean & 2204 & 0.9797 & 517 & 0.1280 & 3.1991 & -0.1021 & 2.2843 & 0.5223 & 1.7620 & 17.5161 \\
\hline Median & -0.4887 & 115 & 1.8454 & 0.2102 & 3.2047 & -0.6818 & 4.4452 & 2.6473 & .1223 & 19.3820 \\
\hline Sk & 2.12 & & & & -0.09 & 2.72 & .97 & -2.72 & 0.62 & -0.03 \\
\hline $\mathrm{Ku}$ & -5.32 & -1.25 & 52 & 1.30 & 0.06 & -8.22 & -1.18 & -8.22 & 0.13 & 1.11 \\
\hline \multicolumn{6}{|c|}{ Korea:KOSPOI-VKOSPI[-5,0,5] } & \multicolumn{5}{|c|}{ Australia:ASX-VASX $[-5,0,5]$} \\
\hline DS & rkospi & rvkospi & erv & AN & CAR & $\operatorname{rasx}$ & rvasx & ervasx & $\mathrm{AR}$ & CAR \\
\hline Mean & -0.1929 & 3.2652 & 1.2079 & 2.0573 & 20.0918 & -0.2074 & 0.5435 & 0.9235 & -0.3800 & 5.1686 \\
\hline Median & -0.4851 & 5.3916 & 492 & 1.3130 & 22.6304 & -0.3343 & 2.1211 & 1.4369 & -0.6652 & 5.2277 \\
\hline Sk & 2.40 & -1.12 & -2.40 & 0.47 & -0.23 & 1.65 & -0.60 & -1.65 & -0.61 & 0.10 \\
\hline $\mathrm{Ku}$ & -6.88 & -1.39 & -6.88 & 0.44 & 0.96 & -4.26 & 0.07 & -4.26 & 0.02 & 1.12 \\
\hline \multicolumn{6}{|c|}{ Canada:IXC-VIXC[-5,0,5] } & \multicolumn{5}{|c|}{ Africa:TOP40-VSAVI[-5,0,5] } \\
\hline $\mathrm{DS}$ & rixc & $\lambda \mathbf{u}$ & $\mathrm{sic}$ & $\mathrm{AR}$ & CAR & rtop40 & rsavi & ersavi & $\mathrm{AR}$ & CAR \\
\hline Mean & -0.2072 & 1.5224 & 1.0866 & 0.4358 & 0.4547 & 0.0425 & 0.0076 & -0.1649 & 0.1726 & -0.6887 \\
\hline Median & -0.2411 & 2.7962 & 1.2505 & 1.8095 & -1.3079 & -0.1885 & 0.5960 & 0.1183 & 0.4777 & 1.0434 \\
\hline $\mathrm{Sk}$ & 0.93 & -0.68 & -0.93 & -0.58 & -0.18 & 0.68 & -1.40 & -0.68 & -1.23 & -0.32 \\
\hline $\mathrm{Ku}$ & -0.02 & 0.08 & -0.02 & 1.22 & -0.33 & 0.78 & -2.20 & 0.78 & -3.65 & 1.98 \\
\hline
\end{tabular}

[Table reports the descriptive statistics surround the Brexit event. The DS represent respectively: returns on stock index, returns on volatility index, and AR and CAR for volatility returns. The event window ranges from $-5,0,+5$, “0” signifies the Brexit announcement day. Sk= Skewness, $\mathrm{Ku}=\mathrm{Kurtosis}]$ 
Table 2 displays the abnormal and cumulative abnormal returns on the investors' fear gauge index of samples stock markets. The table reports the AR and CAR for the event window $[-5,0,+5]$ along with t-statistic. The values shown with bold letters signifies that results are in line with the stated hypotheses. If Brexit event impounds important information about the future stock market volatility and inject the market uncertainty among the market participants. Subsequently, on 24 June 2016 the AR and CAR should be reported positive. One can see clearly from the table all 12-stock market's volatility returns appears to be positive and statistically significant. The decision of exit of Britain from EU caused great amount of fretfulness among the market stakeholders and hence implied volatility increased exponentially and exceeded its normal range. The anxiety and concern about this historical event propel to the investors to more buying pressure on options, which ultimately resulted into higher level of premium and higher expected volatility.

It is known that due to uncertainty about the Brexit decision expected stock market volatility increased significantly. One can clearly examine from the table that CAR appears to be positive (pre-event window, -5) and statistically significant. If the market has adjusted for this information at that moment after the event (post event, +5 ) the returns on the volatility index should be negative. The empirical results show that most of the markets recovered from this event by +2 and $+3-$ day after the event. More specifically, if looking at the Table 2, 2b on the UK market the results are unusual from the other markets. One of the important observations is that the CAR value appears negative on the Brexit decision day and post event i.e. +1 to $+4-$ day market volatility keeps on decreasing with significant t-statistic. This gives an insight that UK market was more uncertain on this event and goes normal as stock prices reflected its fair values. 
Table 2.

\section{SUMMARY STATISTICS OF NORMALAND ABNORMAL FEAR AND GREED RETURNS ON BREXIT EVENT}

\begin{tabular}{|c|c|c|c|c|c|c|c|c|}
\hline \multicolumn{5}{|c|}{ Table 2a AR and CAR surround Brexit event -US-VIX } & \multicolumn{4}{|c|}{$\begin{array}{c}\text { Table } 2 \mathrm{~b} \text { AR and CAR surround Brexit event } \\
\text {-UK-VFSTE }\end{array}$} \\
\hline E-window & AR & CAR & AR-t-stat & CAR-t-stat & AR & CAR & AR-t-stat & CAR-t-stat \\
\hline-5 & 1.3948 & 16.7455 & 0.324 & 3.890 & -3.2318 & -7.1590 & -0.733 & -1.625 \\
\hline-4 & -2.4822 & 15.3507 & -0.577 & 3.566 & -6.8541 & -3.9272 & -1.555 & -0.891 \\
\hline-3 & -12.3243 & 17.8329 & -2.863 & 4.143 & -8.3404 & 2.9269 & -1.893 & 0.664 \\
\hline-2 & 10.9589 & 30.1572 & 2.546 & 7.006 & 0.3485 & 11.2672 & 0.079 & 2.557 \\
\hline-1 & -13.6051 & 19.1983 & -3.161 & 4.460 & 25.8448 & 10.9188 & 5.865 & 2.478 \\
\hline 0 & 20.9672 & 32.8034 & 4.871 & 7.621 & 3.0851 & -14.9260 & 0.700 & -3.387 \\
\hline 1 & 11.4065 & 11.8363 & 2.650 & 2.750 & 1.4794 & -18.0111 & 0.336 & -4.087 \\
\hline 2 & -0.1904 & 0.4298 & -0.044 & 0.100 & -12.8150 & -19.4905 & -2.908 & -4.423 \\
\hline 3 & -3.4000 & 0.6202 & -0.790 & 0.144 & -5.0770 & -6.6755 & -1.152 & -1.515 \\
\hline 4 & 4.3244 & 4.0202 & 1.005 & 0.934 & -1.6354 & -1.5985 & -0.371 & -0.363 \\
\hline 5 & -0.3043 & -0.3043 & -0.071 & -0.071 & 0.0369 & 0.0369 & 0.008 & 0.008 \\
\hline
\end{tabular}

\begin{tabular}{|c|c|c|c|c|c|c|c|c|}
\hline \multicolumn{5}{|c|}{ Table 2c AR and CAR surround Brexit event Swiss-VSMI } & \multicolumn{4}{|c|}{$\begin{array}{l}\text { Table 2d AR and CAR surround Brexit event } \\
\text { German-VDAX }\end{array}$} \\
\hline E-window & $\mathrm{AR}$ & CAR & AR-t-stat & CAR-t-stat & AR & CAR & AR-t-stat & CAR-t-stat \\
\hline-5 & -1.0834 & 44.3925 & -0.284 & 11.626 & 5.9764 & 30.6642 & 1.463 & 7.508 \\
\hline-4 & -3.0102 & 45.4759 & -0.788 & 11.909 & -1.5770 & 24.6877 & -0.386 & 6.045 \\
\hline-3 & -8.2806 & 48.4861 & -2.169 & 12.698 & -1.2079 & 26.2647 & -0.296 & 6.431 \\
\hline-2 & 9.6141 & 56.7667 & 2.518 & 14.866 & 2.5997 & 27.4726 & 0.637 & 6.727 \\
\hline-1 & 15.0284 & 47.1526 & 3.936 & 12.348 & 15.3047 & 24.8729 & 3.747 & 6.090 \\
\hline 0 & 4.9785 & 32.1242 & 1.304 & 8.413 & 6.7290 & 9.5682 & 1.648 & 2.343 \\
\hline 1 & 4.5581 & 27.1457 & 1.194 & 7.109 & -4.2432 & 2.8391 & -1.039 & 0.695 \\
\hline 2 & -4.1780 & 22.5876 & -1.094 & 5.915 & -1.3444 & 7.0823 & -0.329 & 1.734 \\
\hline 3 & 7.6750 & 26.7655 & 2.010 & 7.009 & -1.5323 & 8.4267 & -0.375 & 2.063 \\
\hline 4 & 1.8370 & 19.0905 & 0.481 & 4.999 & 9.5807 & 9.9590 & 2.346 & 2.438 \\
\hline 5 & 0.3763 & 17.2535 & 0.099 & 4.518 & 0.3784 & 0.3784 & 0.093 & 0.093 \\
\hline
\end{tabular}




\begin{tabular}{|c|r|r|r|r|r|r|r|r|}
\hline \multicolumn{5}{|c|}{ Table 2e AR and CAR surround Brexit event Eurozone- } & \multicolumn{3}{c|}{ Table 2f AR and CAR surround Brexit event } \\
China-VHSI \\
\hline E-window & \multicolumn{1}{|c|}{ AR } & CAR & AR-t-stat & CAR-t-stat & AR & CAR & AR-t-stat & CAR-t-stat \\
\hline-5 & -4.4193 & 34.6340 & -1.135 & 8.898 & -2.8091 & 0.0835 & -0.636 & 0.019 \\
\hline-4 & 0.5869 & 39.0533 & 0.151 & 10.033 & -1.5778 & 2.8926 & -0.357 & 0.655 \\
\hline-3 & -11.6959 & 38.4663 & -3.005 & 9.882 & -6.0384 & 4.4704 & -1.367 & 1.012 \\
\hline-2 & 3.9660 & 50.1622 & 1.019 & 12.887 & -3.5226 & 10.5089 & -0.797 & 2.379 \\
\hline-1 & 24.0902 & 46.1962 & 6.189 & 11.868 & -0.5013 & 14.0314 & -0.113 & 3.176 \\
\hline 0 & 11.9543 & 22.1060 & 3.071 & 5.679 & 11.3141 & 14.5327 & 2.561 & 3.289 \\
\hline 1 & $\mathbf{3 . 3 6 0 1}$ & $\mathbf{1 0 . 1 5 1 7}$ & 0.863 & $\mathbf{2 . 6 0 8}$ & $\mathbf{2 . 8 1 4 6}$ & 3.2186 & 0.637 & 0.729 \\
\hline 2 & -1.9444 & 6.7916 & -0.500 & 1.745 & 4.4064 & 0.4040 & 0.997 & 0.091 \\
\hline 3 & 4.4963 & 8.7360 & 1.155 & 2.244 & -4.6570 & -4.0023 & -1.054 & -0.906 \\
\hline 4 & 1.5208 & 4.2397 & 0.391 & 1.089 & -3.2953 & 0.6547 & -0.746 & 0.148 \\
\hline 5 & 2.7189 & 2.7189 & 0.699 & 0.699 & 3.9500 & 3.9500 & 0.894 & 0.894 \\
\hline
\end{tabular}

\begin{tabular}{|c|c|c|c|c|c|c|c|c|}
\hline \multicolumn{6}{|c|}{ Table 2g AR and CAR surround Brexit event India-Nifty- } & \multicolumn{3}{c|}{ Table 2h AR and CAR surround Brexit event } \\
\hline E-window & AR & CAR & AR-t-stat & CAR-t-stat & AR & CAR & AR-t-stat & CAR-t-stat \\
\hline-5 & -4.0796 & 1.4077 & -0.974 & 0.336 & -3.2371 & 19.3820 & -0.588 & 3.521 \\
\hline-4 & 2.2827 & 5.4874 & 0.545 & 1.310 & -2.4961 & 22.6191 & -0.453 & 4.109 \\
\hline-3 & -4.5252 & 3.2047 & -1.080 & 0.765 & -5.5596 & 25.1152 & -1.010 & 4.563 \\
\hline-2 & -2.1254 & 7.7299 & -0.507 & 1.845 & -4.5530 & 30.6748 & -0.827 & 5.573 \\
\hline-1 & 4.8840 & 9.8553 & 1.166 & 2.352 & 13.4703 & 35.2278 & 2.447 & 6.400 \\
\hline 0 & $\mathbf{0 . 2 1 0 2}$ & $\mathbf{4 . 9 7 1 2}$ & 0.050 & 1.187 & $\mathbf{4 . 4 8 5 7}$ & $\mathbf{2 1 . 7 5 7 5}$ & 0.815 & 3.953 \\
\hline 1 & 2.8924 & 4.7610 & 0.690 & 1.136 & 6.9782 & 17.2718 & 1.268 & 3.138 \\
\hline 2 & 5.7852 & 1.8687 & 1.381 & 0.446 & 6.7217 & 10.2936 & 1.221 & 1.870 \\
\hline 3 & -4.6295 & -3.9166 & -1.105 & -0.935 & -1.0696 & 3.5719 & -0.194 & 0.649 \\
\hline 4 & 1.6051 & 0.7129 & 0.383 & 0.170 & 2.5191 & 4.6414 & 0.458 & 0.843 \\
\hline 5 & -0.8922 & -0.8922 & -0.213 & -0.213 & 2.1223 & 2.1223 & 0.386 & 0.386 \\
\hline
\end{tabular}




\begin{tabular}{|c|c|c|c|c|c|c|c|c|}
\hline \multicolumn{5}{|c|}{$\begin{array}{l}\text { Table 2i AR and CAR surround Brexit event Korea- KOSPI- } \\
\text { VKOSPI }\end{array}$} & \multicolumn{4}{|c|}{$\begin{array}{c}\text { Table 2j AR and CAR surround Brexit event } \\
\text { Australia-ASX-VASX }\end{array}$} \\
\hline E-window & AR & CAR & AR-t-stat & CAR-t-stat & AR & CAR & AR-t-stat & CAR-t-stat \\
\hline-5 & -0.6582 & 22.6304 & -0.145 & 5.002 & -9.4075 & -4.1798 & -2.013 & -0.894 \\
\hline-4 & 1.3130 & 23.2886 & 0.290 & 5.147 & -0.7416 & 5.2277 & -0.159 & 1.119 \\
\hline-3 & -6.7393 & 21.9756 & -1.490 & 4.857 & -5.8330 & 5.9693 & -1.248 & 1.277 \\
\hline-2 & -6.6762 & 28.7149 & -1.476 & 6.347 & -3.2365 & 11.8024 & -0.693 & 2.526 \\
\hline-1 & -2.8346 & 35.3911 & -0.627 & 7.822 & 3.8933 & 15.0388 & 0.833 & 3.218 \\
\hline 0 & 14.0410 & 38.2257 & 3.103 & 8.449 & 1.8499 & 11.1455 & 0.396 & 2.385 \\
\hline 1 & 8.3488 & 24.1847 & 1.845 & 5.346 & 5.6199 & 9.2956 & 1.203 & 1.989 \\
\hline 2 & 10.7839 & 15.8360 & 2.384 & 3.500 & 4.7625 & 3.6758 & 1.019 & 0.787 \\
\hline 3 & 1.0868 & 5.0521 & 0.240 & 1.117 & -1.7179 & -1.0867 & -0.368 & -0.233 \\
\hline 4 & 2.2196 & 3.9652 & 0.491 & 0.876 & 1.2964 & 0.6312 & 0.277 & 0.135 \\
\hline 5 & 1.7456 & 1.7456 & 0.386 & 0.386 & -0.6652 & -0.6652 & -0.142 & -0.142 \\
\hline
\end{tabular}

\begin{tabular}{|c|r|c|c|c|c|c|c|c|}
\hline \multicolumn{3}{|c|}{ Table 2k AR and CAR surround Brexit event Canada-SPTX- } & \multicolumn{3}{|c|}{ Table 21 AR and CAR surround Brexit event } \\
\hline E-window & \multicolumn{1}{|c|}{ AR } & CAR & AR-t-stat & CAR-t-stat & AR & CAR & AR-t-stat & CAR-t-stat \\
\hline-5 & 1.5457 & 4.7941 & 0.204 & 0.634 & -0.5834 & 1.8984 & -0.239 & 0.777 \\
\hline-4 & 8.8192 & 3.2485 & 1.165 & 0.429 & 0.4777 & 2.4818 & 0.195 & 1.015 \\
\hline-3 & -15.8116 & -5.5707 & -2.089 & -0.736 & 0.1757 & 2.0042 & 0.072 & 0.820 \\
\hline-2 & 11.5487 & 10.2409 & 1.526 & 1.353 & 0.5581 & 1.8284 & 0.228 & 0.748 \\
\hline-1 & -19.0048 & -1.3079 & -2.511 & -0.173 & 0.2270 & 1.2704 & 0.093 & 0.520 \\
\hline 0 & 7.5126 & 17.6970 & 0.993 & 2.339 & $\mathbf{3 . 3 8 3 4}$ & 1.0434 & 1.384 & 0.427 \\
\hline 1 & 15.3229 & 10.1844 & 2.025 & 1.346 & 0.6237 & -2.3400 & 0.255 & -0.957 \\
\hline 2 & 1.8095 & -5.1385 & 0.239 & -0.679 & 1.6441 & -2.9638 & 0.672 & -1.212 \\
\hline 3 & 12.4427 & -6.9481 & 1.644 & -0.918 & -1.0912 & -4.6078 & -0.446 & -1.885 \\
\hline 4 & -16.5837 & -19.3908 & -2.192 & -2.562 & 1.1577 & -3.5166 & 0.474 & -1.438 \\
\hline 5 & -2.8070 & -2.8070 & -0.371 & -0.371 & -4.6743 & -4.6743 & -1.912 & -1.912 \\
\hline
\end{tabular}


Table 3.

BREXIT: INVESTOR FEAR AND STOCK RETURNS

\begin{tabular}{|c|c|c|c|c|}
\hline \multicolumn{5}{|c|}{ Panel A } \\
\hline Returns & Full & Pre-event & Event Day & Post-event \\
\hline ARVIX & $1.1244^{\S}$ & -0.4293 & $6.6301^{\S}$ & $1.3943^{\S}$ \\
\hline t-stat & $1.9603^{b}$ & -0.4239 & $5.9813^{\mathrm{a}}$ & $2.0145^{\mathrm{b}}$ \\
\hline Adj. $R^{2}$ & 0.1730 & 0.1218 & 0.0085 & 0.0048 \\
\hline F-stat & $2.3045^{\mathrm{c}}$ & $2.5454^{\mathrm{b}}$ & $3.0860^{\mathrm{a}}$ & $4.0191^{\mathrm{a}}$ \\
\hline \multicolumn{5}{|l|}{ Panel B } \\
\hline CARVIX & $11.202^{\S}$ & $17.958^{\S}$ & $15.399^{\S}$ & $3.502^{\S}$ \\
\hline t-stat & $17.643^{\mathrm{a}}$ & $34.111^{\mathrm{a}}$ & $6.012^{\mathrm{a}}$ & $4.880^{\mathrm{a}}$ \\
\hline Adj. $R^{2}$ & 0.770 & 0.638 & 0.224 & 0.664 \\
\hline F-stat & $21.908^{\mathrm{a}}$ & $60.694^{\mathrm{a}}$ & $3.880^{\mathrm{a}}$ & $8.760^{\mathrm{a}}$ \\
\hline \multicolumn{5}{|l|}{ Panel C } \\
\hline RVIX & $2.2366^{\AA}$ & -0.9602 & $4.2713^{\S}$ & $5.2846^{\S}$ \\
\hline t-stat & $3.5661^{\mathrm{a}}$ & -0.8807 & $2.8026^{\mathrm{a}}$ & $7.9788^{\mathrm{a}}$ \\
\hline Adj. $\mathrm{R}^{2}$ & 0.3544 & 0.3220 & 0.5555 & 0.3813 \\
\hline F-stat & $4.4246^{\mathrm{a}}$ & $2.8684^{\mathrm{b}}$ & $5.9998^{\mathrm{a}}$ & $3.4241^{\mathrm{b}}$ \\
\hline \multicolumn{5}{|l|}{ Panel D } \\
\hline RINDX & $-0.2099^{\S}$ & 0.1457 & 1.3142 & $-0.8444^{\S}$ \\
\hline t-stat & $-1.9433^{c}$ & 0.7494 & 1.0809 & $-8.1430^{a}$ \\
\hline Adj. $R^{2}$ & 0.6118 & 0.6346 & 0.2454 & 0.4148 \\
\hline F-stat & $10.8314^{\mathrm{a}}$ & $7.8313^{\mathrm{a}}$ & $4.2518^{\mathrm{a}}$ & $3.7884^{\mathrm{a}}$ \\
\hline Fixed effects & Yes & Yes & No & Yes \\
\hline
\end{tabular}

[Table reports the estimate on stock market returns on volatility index (implied volatility index) and underlying stock indices. The first two panel report the abnormal and cumulative abnormal returns on implied volatility index followed by the Brexit event window. The last two panels show the estimate on returns of VIX and stock indices around Brexit referendum. $\S=$ slope estimated as hypothesized. Significant at $\left.{ }^{\mathrm{a}} 1 \%,{ }^{\mathrm{b}} 5 \%,{ }^{\mathrm{c}} 10 \%\right]$

\subsection{Investors' fear and Brexit}

The present work examines the 12 major implied volatility indices on the Britain's exit referendum from the European Union. The global equity markets are closely interlinked, the political uncertainty creates market instability and high de- 
grees of volatility during the political decisions are announced. The abnormal and cumulative abnormal returns are measured around the Brexit event and a panel dataset of 12 countries has been prepared. The rational of constructing ARVIX and CARVIX based panel data is to investigate the effects of Brexit during the event window and country specific effects.

Table 3 reports the estimates on stock market returns measured during the Brexit event window. The panel regression performed for both cross sections (countries) and time (event window). Panel A of Table 3 shows the estimate for ARVIX (abnormal returns on volatility index). The estimates on full event window, event day and post event appear positive and statistically significant. This implies that Brexit has increased the stock market uncertainty and expected stock market volatility remains more volatile around the Brexit referendum. Panel B also reports the statistically significant estimates on CARVIX. The estimate 17.96 (pre -event window) with significant $\mathrm{t}$-stat indicate that stock market volatility was increased by about $18 \%$ due unknown outcome the Brexit referendum. Moreover, once the results announced, the event day and post event estimate appear to be positive significant but small on the counter part of pre-event window. It is apparent from the Panel C and D that market has reported significant negative returns and positive returns on the investors' fear gauge index. This signals that investors are taking short positions by selling the less profitable stocks and taking the longpositions for the safer stocks.

Table 4 explains the asymmetric relations between the stock market returns and expected stock market volatility. The stock index and volatility index are inversely related, the negative returns increase the stock market uncertainty followed by increased volatility. In order to examine the asymmetric impact of Brexit the ARVIX and CARVIX are regressed over the respective stock indices returns. Panel A, the slope of the RINDX for entire event window appears to be 1.73 (significant), this indicate that ARVIX was increased at the rate of $1.73 \%$ followed by the Brexit event and it is also true for the CARVIX (see Panel B). One of the interesting observations from the Table 4 is that around the Brexit referendum RINDX has shown positive significant impact on ARVIX and CARVIX. One of the responsible reasons for positive ARVIX and CARVIX can be the erosion of the stock prices, as some of the stocks became less profitable after the Brexit announcement. The estimates on RINDX for the ARVIX and CARVIX on the post Brexit, appears respectively 2.79 and 3.11 and statistically significant. This indicate that Post referendum announcement of the Britain exit from the EU has increased the market uncertainty globally which is gauged in terms of investors' sentiment index. One more interesting finding apparent from the table that VIX level was increased by 5 to 11-point basis followed by the Brexit news. 
Table 4.

\section{BREXIT: INVESTOR FEAR GAUGE INDEX-VIX}

\begin{tabular}{|c|c|c|c|c|}
\hline \multicolumn{5}{|l|}{ Panel A } \\
\hline $\begin{array}{c}\text { Dependent } \\
\text { Variable: ARVIX }\end{array}$ & Full & Pre-event & Event Day & Post-event \\
\hline Intercept & 1.4884 & -0.7156 & 6.9948 & 3.7520 \\
\hline t-stat & $2.6873^{a}$ & -0.7495 & $3.1625^{\mathrm{a}}$ & $3.7261^{\text {a }}$ \\
\hline RINDX & $1.7343^{\S \S}$ & $1.9647^{\S}$ & $0.4624^{\S \S}$ & $2.7920^{\S \S}$ \\
\hline t-stat & $3.6076^{\mathrm{a}}$ & $2.6717^{\mathrm{a}}$ & 0.4264 & $3.0199^{a}$ \\
\hline Adj. $R^{2}$ & 0.2544 & 0.2293 & 0.0179 & 0.1599 \\
\hline $\begin{array}{l}\text { F-stat } \\
\text { Fixed effects }\end{array}$ & $\begin{array}{c}3.0316^{\mathrm{a}} \\
\text { Yes }\end{array}$ & $\begin{array}{c}2.0970^{\circ} \\
\text { Yes }\end{array}$ & $\begin{array}{l}0.1818 \\
\text { No } \\
\end{array}$ & $\begin{array}{c}1.7017^{\mathrm{c}} \\
\text { Yes }\end{array}$ \\
\hline \multicolumn{5}{|l|}{ Panel B } \\
\hline $\begin{array}{c}\text { Dependent } \\
\text { Variable: } \\
\text { CARVIX }\end{array}$ & Full Period & Pre-event & Event Day & Post-event \\
\hline Intercept & 11.3120 & 17.9454 & 17.8361 & 6.1307 \\
\hline t-stat & $17.5085^{\mathrm{a}}$ & $33.5019^{a}$ & $6.1566^{\mathrm{a}}$ & $5.972^{\mathrm{a}}$ \\
\hline RINDX & $0.5242^{\S \S}$ & $0.0887^{\S \S}$ & -2.2144 & $3.1129^{\S \S}$ \\
\hline t-stat & 0.9347 & 0.2149 & -1.3984 & $3.3027^{\mathrm{a}}$ \\
\hline Adj. $R^{2}$ & 0.7699 & 0.6368 & 0.3006 & 0.7254 \\
\hline F-stat & $5.0191^{\mathrm{a}}$ & $8.7599^{a}$ & $3.4241^{\mathrm{a}}$ & $3.7884^{\mathrm{a}}$ \\
\hline Fixed effects & Yes & Yes & No & Yes \\
\hline
\end{tabular}

[Table reports the estimates on abnormal and cumulative abnormal returns on VIX in association with respective stock indices returns under Brexit. $\S \S=$ slope estimated as hypothesized. Significant at $\left.{ }^{\mathrm{a}} 1 \%,{ }^{\mathrm{b}} 5 \%,{ }^{\mathrm{c}} 10 \%\right]$

The empirical evidences reported here on the Brexit event are limited to the equity markets only, while there are some other markets such as exchange rate, crude oil and Bond market e.g. (Shaikh, 2017) that are also responsive to the historical political decisions. 


\section{Conclusion}

The historical vote of Britain's exit from EU stumbled the global equity market, the U.S. market heart by around 2.4 percent while European markets such as Germany(DAX) lost 3 percent and London(FTSE) more than 2.6 percent (see Brexit, 2016). Indeed, a great amount of distress is more likely to happen between UK and EU on this Brexit decision. The paper demonstrated the investors' sentiment on the Brexit events that took place on 24 June 2016. We sampled 12 international equity markets encompassed Europe, UK, Asia -pacific, US, Canada and Africa. The event window consisted of 11 -day and estimation window ranged from January 2015 to July 2016. The empirical findings clearly show that implied volatility index is the investors' fear and greed index and regarded the Brexit event in the portfolio assortment. The event window evidently exhibited that abnormal and cumulative volatility returns appear to be positive and significant. This indicates that stock prices reflect its fair value due to such event. On the pre-announcement of Brexit, the overall equity market was in greater tension and once the poll declared fear was gauged in the volatility returns.

The empirical evidences emphasis that in a long-term perspective Brexit will downgrade the global rating of Britain. The investment and banking business may shift from EU to UK in the next few years e.g. (Fernandes, 2016) The abnormal returns and cumulative abnormal returns on the expected volatility index clearly show that stocks entered into prolonged period of volatility. Plausibly, there will be contagion effects of Brexit not only in the equity markets but also a spillover effects on the exchange rate, Bond market and logistic business e.g. (Tielmann \& Schiereck, 2017).

The results are consistent with the market efficiency, and options trading contain enough information to explain future stock market volatility. Now-a-days volatility became an asset class for trading. For the hedging of volatility CBOE has introduced volatility product called volatility futures and options on VIX. Definitely, the work has practical implications to volatility traders and portfolio managers. The Brexit has raised the uncertainty and turbulence in the financial markets, hence policy makers in EU and UK both have to come together to build competitive multilateral financial strategy. 


\section{References:}

Äijö, J. (2008). Implied volatility term structure linkages between VDAX, VSMI and VSTOXX volatility indices. Global Finance Journal, 18(3), 290-302. DOI: https:// doi.org/10.1016/j.gfj.2006.11.003.

Antonakakis, N., Chatziantoniou, I., \& Filis, G. (2013). Dynamic co-movements of stock market returns, implied volatility and policy uncertainty. Economics Letters, 120(1), 87-92. DOI : https://doi.org/10.1016/j.econlet.2013.04.004.

Barbić, T., \& Čondić-Jurkić, I. (2017). Do fiscal varia bles affect stock market returns in eu countries? Ekonomski pregled,, 68(3), 253-266. URL: https://hrcak.srce.hr/184588.

Black, F. (1976). Studies of the stock price volatility changes. Proceedings of the 1976 meeting of the American Statistical Association, Business and Economical Statistics Section, (pp. pp. 177-181).

Blair, B. J., Poon, S.-H., \& Taylor, S. J. (2001). Forecasting S\&P 100 volatility: the incremental information content of implied volatilities and high-frequency index returns. Journal of Econometrics, 105(1), 5-26 DOI: https://doi.org/10.1007/978-0387-77117-5_88.

BREXIT. (2016). BREXIT 2016 Policy analysis from the Centre for Economic Performance. London: Centre for Economic Performance London School of Economics and Political Science.

Campbell, J., \& Hentschel, L. (1992). No News is Good News: An Asymmetric Model of Changing Volatility in Stock Returns. Journal of Financial Economics, 31(3), 281318 DOI: https://doi.org/10.1016/0304-405X(92)90037-X.

Chen, E.-T. J., \& Clements, A. (2007). S\&P 500 implied volatility and monetary policy announcements. Finance Research Letters, 4(4), 4(4), 227-232 DOI: https://doi. org/10.1016/j.frl.2007.07.002.

Christensen, B., \& Prabhala, N. (1998). The relation between implied and realized volatility. Journal of Financial Economics, 50(2), 50(2), 125-150 DOI: https://oi. org/10.1016/S0304-405X(98)00034-8.

Christie, A. A. (1982). The stochastic behavior of common stock variances:value, leverage and interest rate effects. Journal of Financial Economics, 10(4), 407-432 DOI: https://doi.org/10.1016/0304-405X(82)90018-6.

Dedi, L., \& Škorjanec, D. (2017). Volatilities and equity market returns in selected Central and Southeast European countries. Ekonomski pregled, , 68(4), 384-398 URL: https://hrcak.srce.hr/187555.

Fernandes, M. C. (2016). How Will Brexit Impact Deposit Balances in the UK? SSRNid2824556, 1-32.

Fleming, J., Ostdiek, B., \& Whaley, R. E. (1995). Predicting stock market volatility: A new measure. Journal of Futures Markets, 15(3), 265-302 DOI: https://doi.org/10.1002/ fut.3990150303. 
French, K. R., Schwert, G. W., \& Stambaugh, R. F. (1987). Expected stock returns and volatility. Journal of Financial Economics, 19(1), 3-29 DOI: https://doi.org/10.1016/0304405X(87)90026-2.

Giot, P. (2005). Relationships Between Implied Volatility Indexes and Stock Index Returns. The Journal of Portfolio Management, 31(3), 92-100 DOI: http://dx.doi.org/10.3905/ jpm.2005.500363.

Hamao, Y., Masulis, R. W., \& Ng, V. (1990). Correlations in price changes and volatility across international stock markets. Review of Financial studies, 3(2), 281-307 URL: http://www.jstor.org/stable/2962024.

Hansen, C. S. (2001). The relation between implied and realized volatility in the Danish option and equity markets. Accounting and Finance, 41(3), 41(3), 197-228 DOI: https://doi.org/10.1111/1467-629X.00059.

Kearney, A., \& Lombra, R. (2004). Stock market volatility, the news, and monetary policy. Journal of Economics and Finance, 28(9), 28(2), 252-259 DOI: https://doi. org/10.1007/BF02761615.

Miller, V. (2016). Brexit: impact across policy areas. London: House of Commons Library and Devolved Research Services.

Nikkinen, J., \& Sahlström, P. (2001). Impact of Scheduled U.S. Macroeconomic News on Stock Market Uncertainty: A Multinational Perspecive. Multinational Finance Journal, , 5(2), 129-148.

Nikkinen, J., \& Sahlström, P. (2004). Impact of the federal open market committee's meetings and scheduled macroeconomic news on stock market uncertainty. International Review of Financial Analysis, 13(1), 1-12, DOI: https://doi.org/10.1016/j. irfa.2004.01.001.

Oehler, A., Horn, M., \& Wendt, S. (2017). Brexit: Short-term Stock Price Effects and the Impact of Firm-level Internationalization. Finance Research Letters., 22,175-181 DOI: https://doi.org/10.1016/j.frl.2016.12.024.

Shaikh, I. (2017). The 2016 U.S. presidential election and the Stock, FX and VIX markets. The North American Journal of Economics and Finance, 42, 546-563. DOI: https:/ doi.org/10.1016/j.najef.2017.08.014.

Shaikh, I. (2018). Investors' fear and stock returns: Evidence from National Stock Exchange of India. Engineering Economics,, 29(1), 4-12 DOI: http://dx.doi.org/10.5755/j01. ee.29.1.14966.

Shaikh, I., \& Padhi, P. (2015). The implied volatility index: Is 'investor fear gauge'or 'forward-looking'?. Borsa Istanbul Review, , 15(1), 44-52. DOI: https://doi.org/10.1016/j. bir.2014.10.001.

Shaikh, I., \& Padhi, P. (2016). On the relationship between implied volatility index and equity index returns. Journal of Economic Studies, 43(1), 27-47 DOI: https://doi. org/10.1108/JES-12-2013-0198.

Smales, L. A. (2016). "Brexit": A Case Study in the Relationship Between Political and Financial Market Uncertainty. International Review of Finance, 17(3), 451-459 DOI: https://doi.org/10.1111/irfi.12100. 
Tielmann, A., \& Schiereck, D. (2017). Arising borders and the value of logistic companies: Evidence from the Brexit referendum in Great Britain. Finance Research Letters, 20(C), 22-28 DOI: https://doi.org/10.1016/j.frl.2016.08.006.

Wagner, N., \& Szimayer., A. (2004). Local and spillover shocks in implied market volatility: evidence for the US and Germany. Research in international Business and Finance, 18(3), 237-251 DOI: https://doi.org/10.1016/j.ribaf.2004.04.008.

Whaley, R. E. (2000). The Investor Fear Gauge. The Journal of Portfolio Management, 26(3), 12-17 DOI: https://doi.org/10.3905/jpm.2000.319728.

Whaley, R. E. (2008). Understanding VIX. Available at SSRN 1296743, http://ssrn.com/ abstract $=1296743,1-12$. 


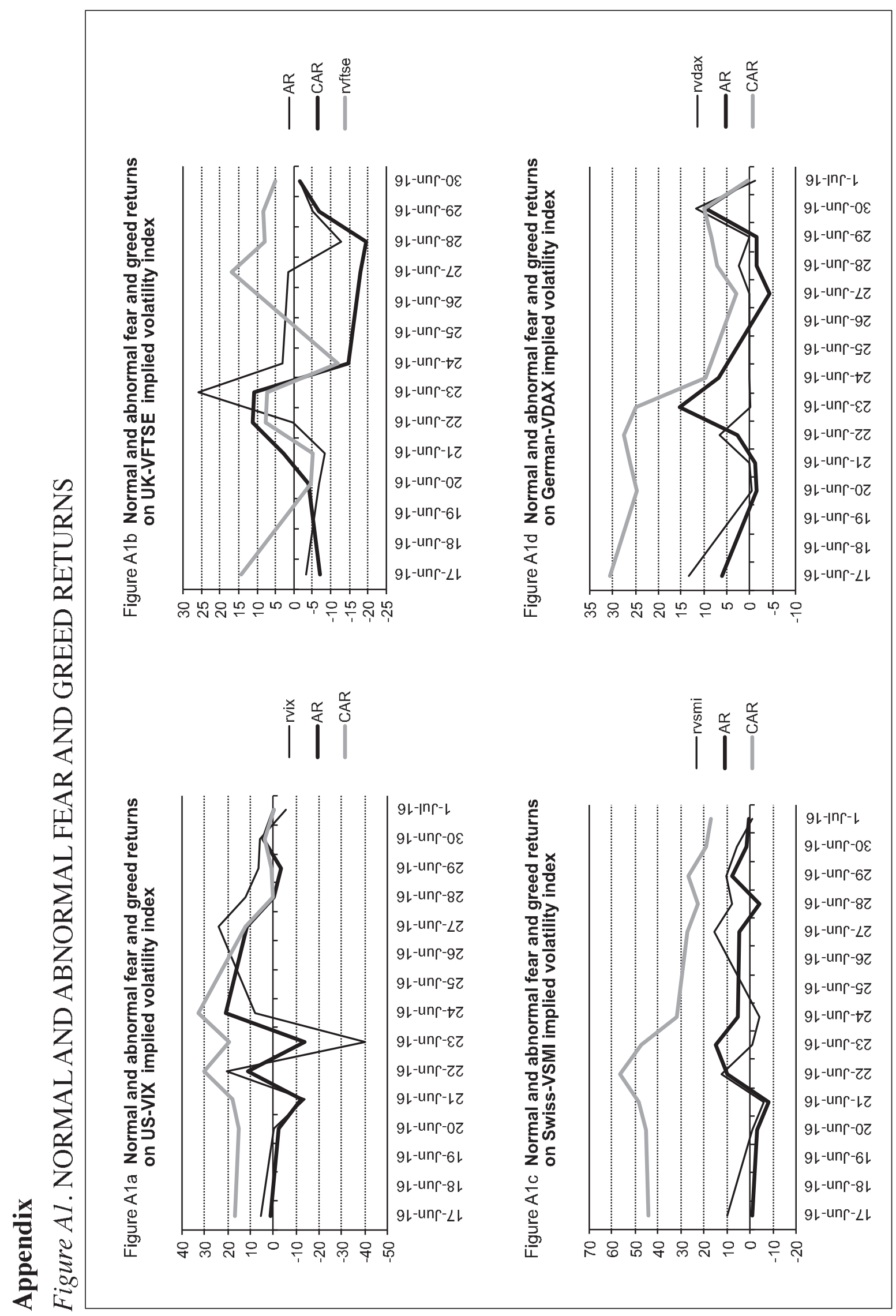




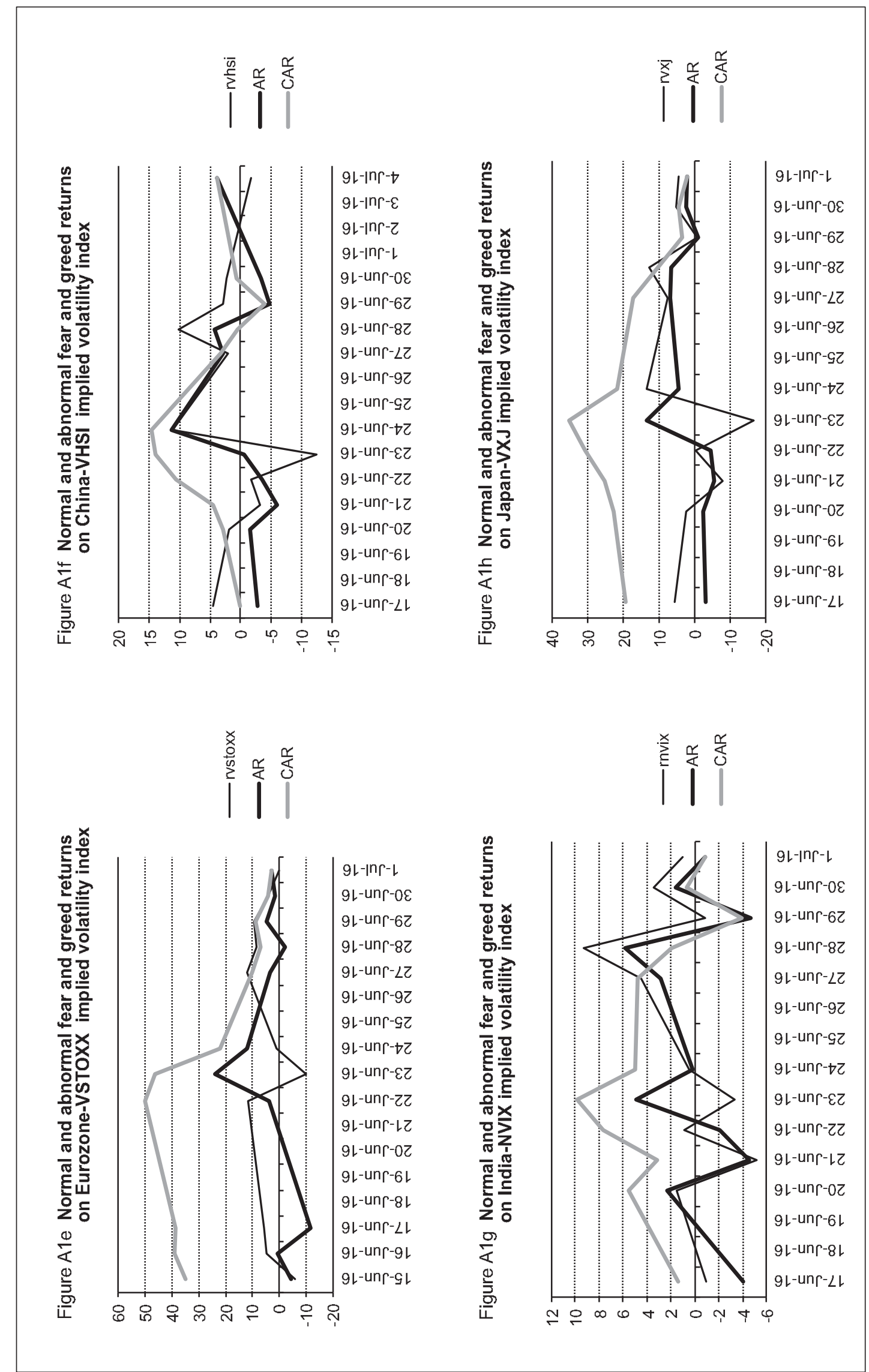




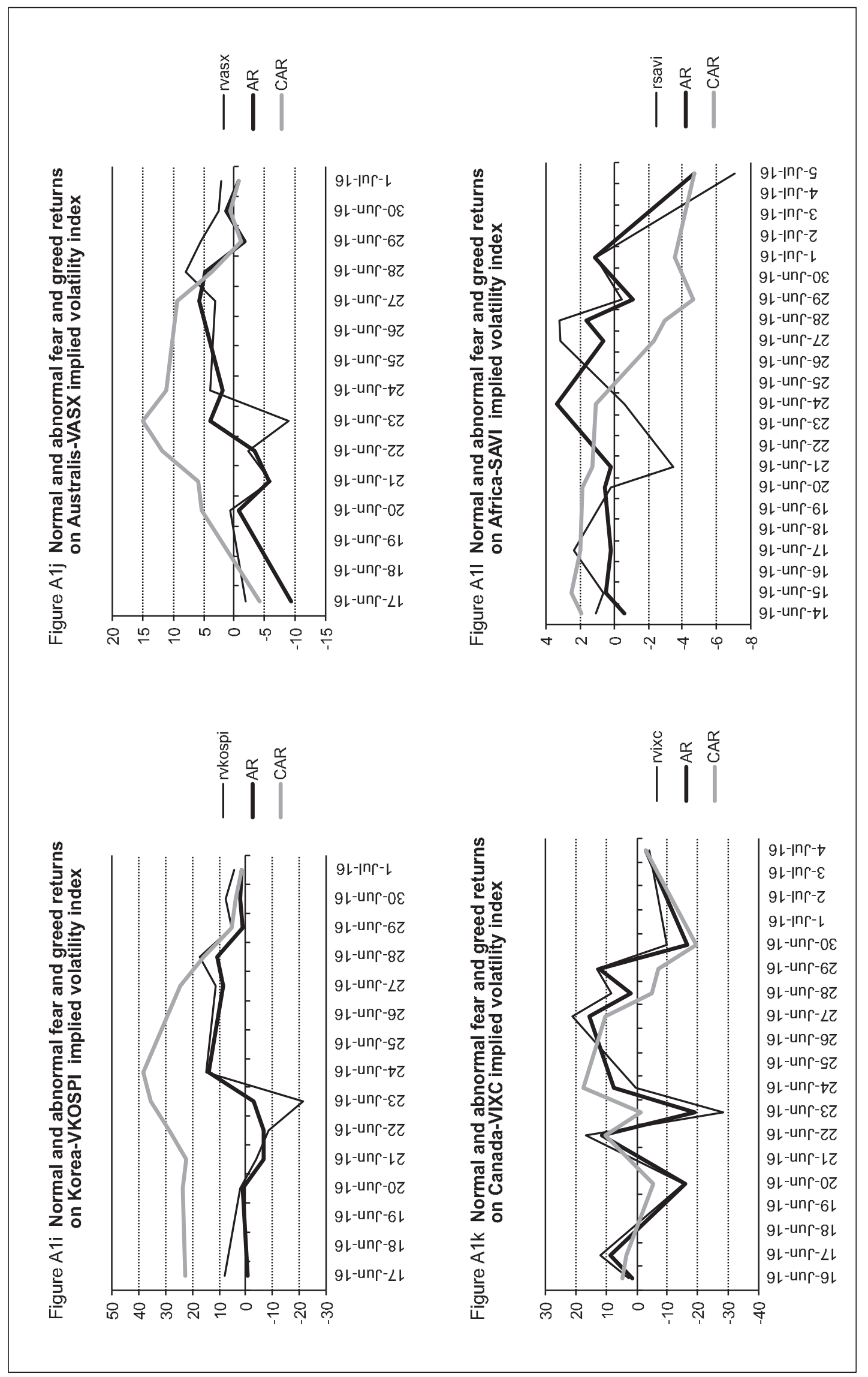


Figure A2. RETURN BEHAVIOR ON STOCK INDEX AND VOLATILITY INDEX

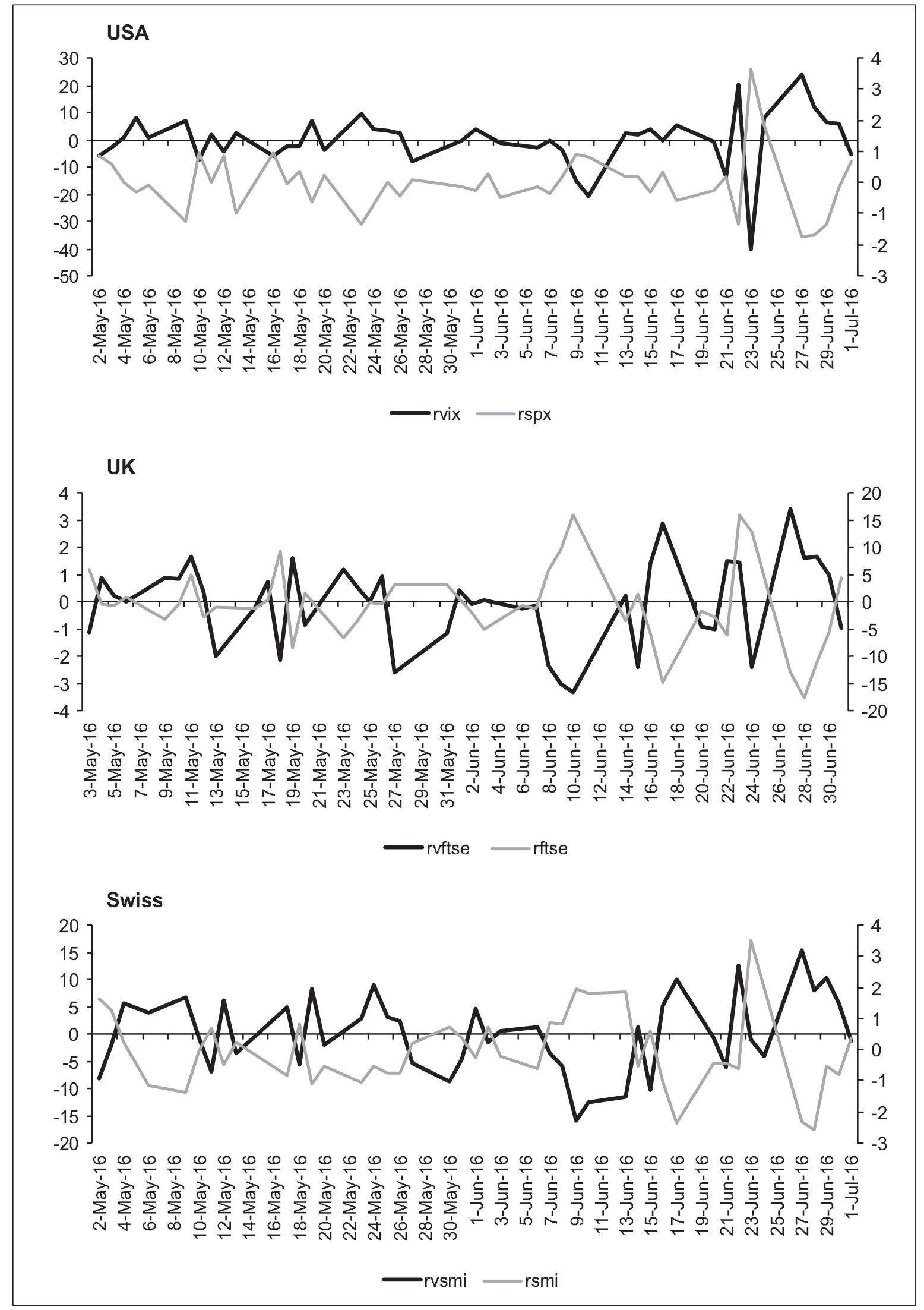




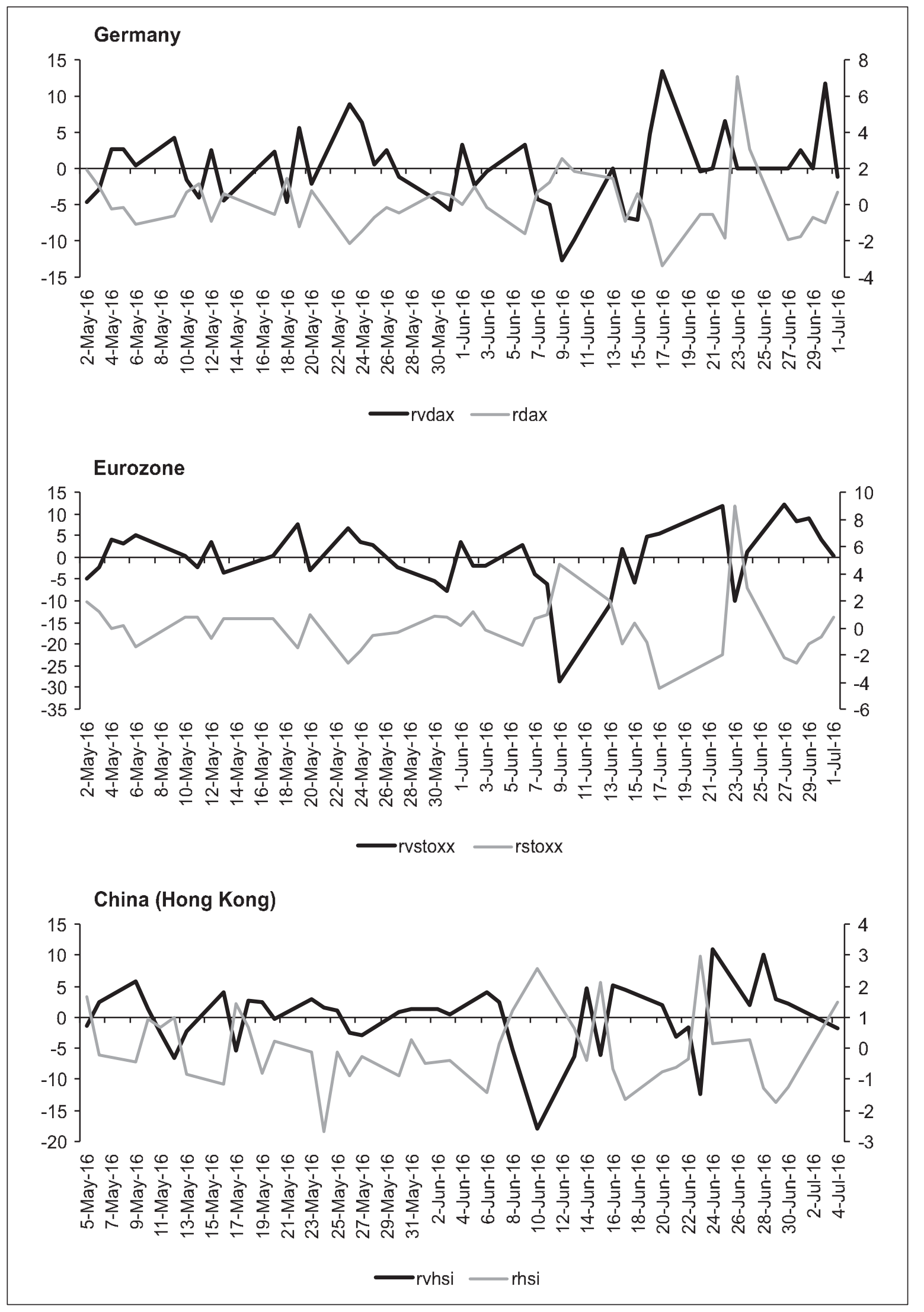




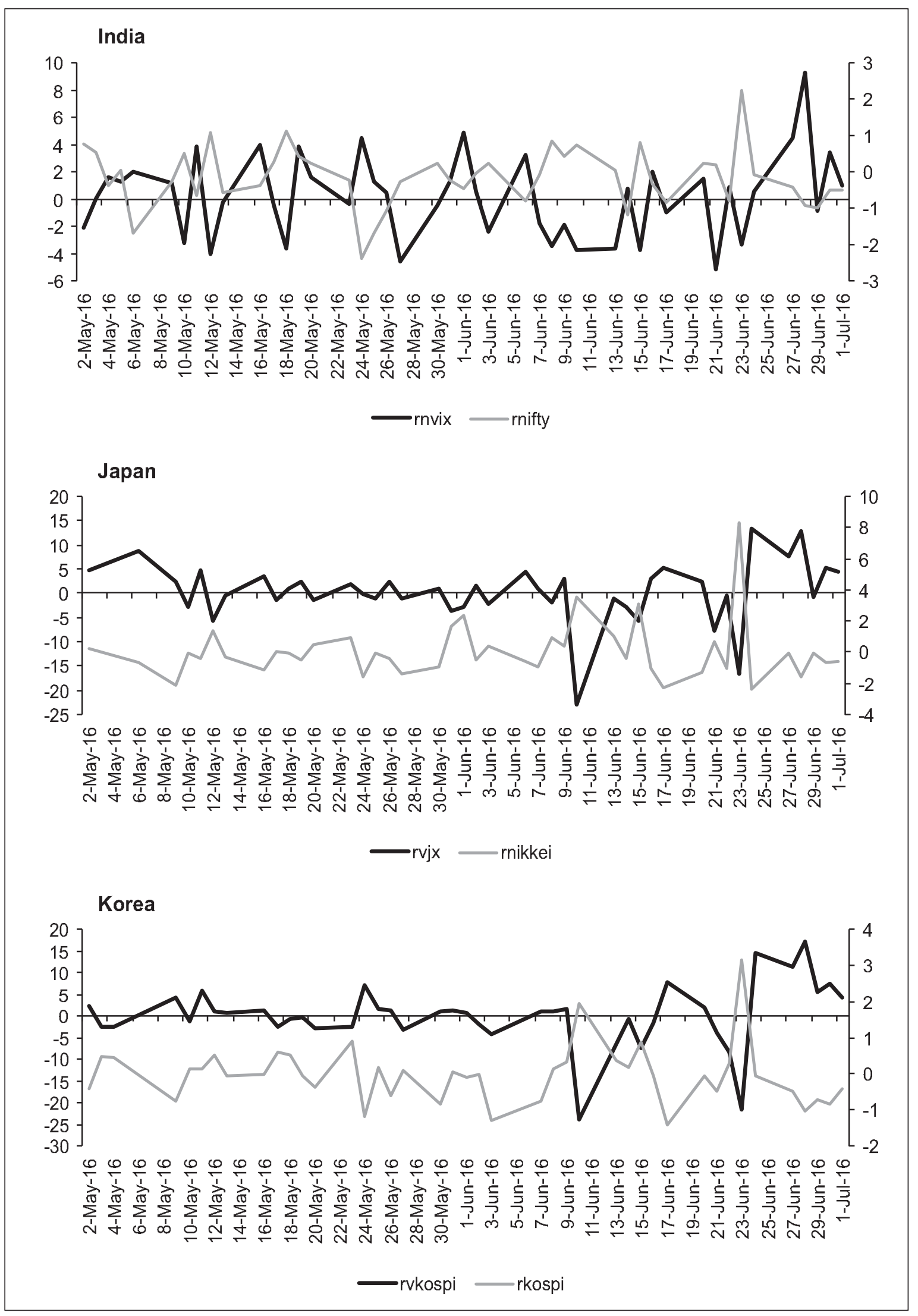




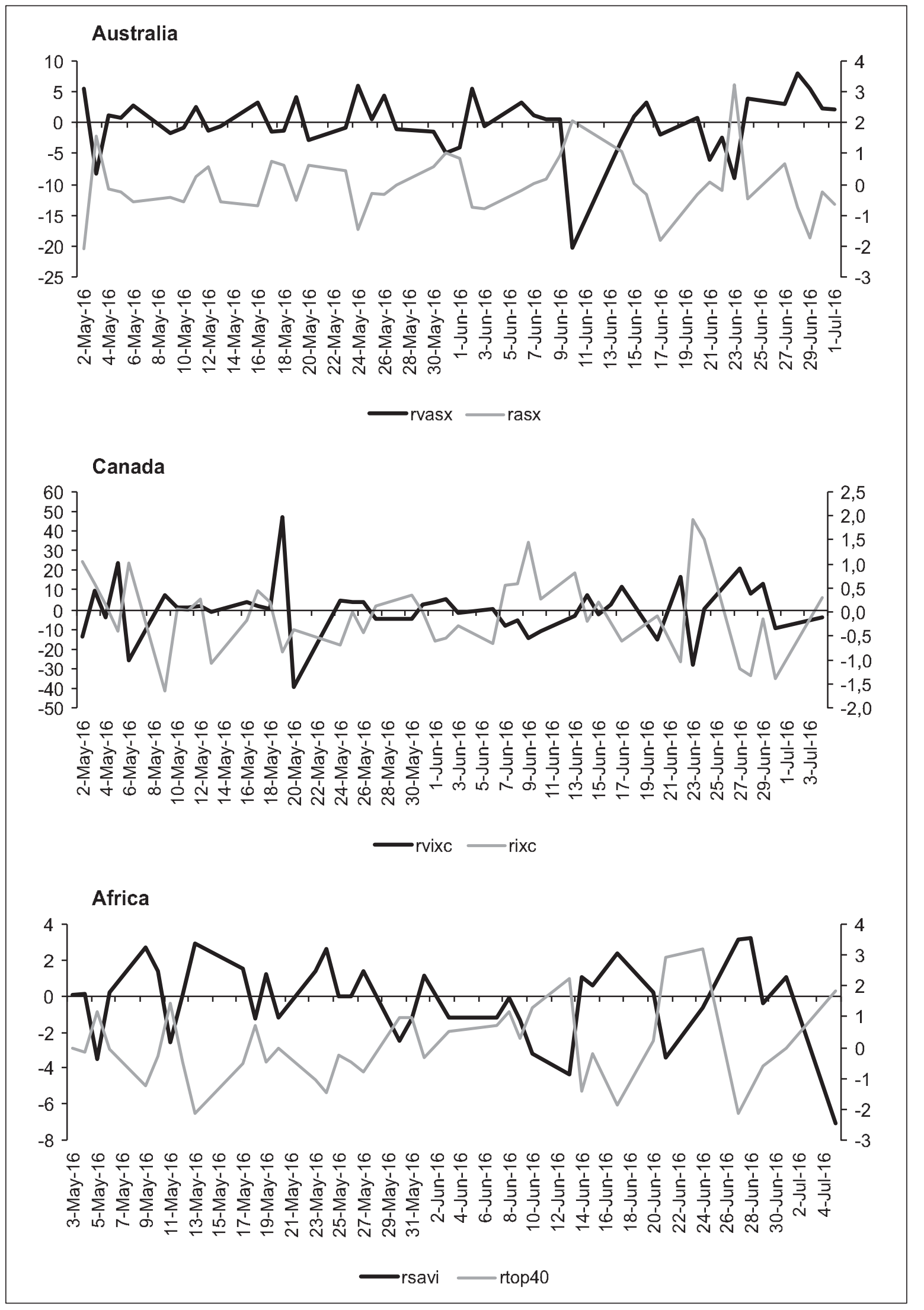




\section{BREXIT I STRAH INVESTITORA}

\section{Sažetak}

Ovaj rad istražuje najvažnije implicitne indekse volatilnosti Eurozone, Azije i Pacifika, Afrike, Kanade i SAD-a vezane uz Brexit u Velikoj Britaniji. Budući da međunarodni gospodarski događaji signaliziraju nove informacije sudionicima na tržištu, na 12 globalnih tržišta je Brexit ocijenjen indeksima volatilnosti kao što su VFTSE, VIX, VDAX, VSMI, VSTOXX, VXJ, VHSI, VKOSPI, NVIX, VASX, VXIC i SAVI. Na dan odluke o Brexitu zabilježen je veliki strah (20$36 \%$ indeksa). Iznadprosječni prinosi i kumulativni iznadprosječni prinosi indeksa volatilnosti su u manjem dijelu bili pozitivni, dok je većina globalnih tržišta dionica iskazala negativne trendove vezano uz Brexit. Kako bi se istražio „strah i pohlepa” investitora vezano uz Brexit, razmotreno je razdoblje od 11 dana. Rezultati upućuju na to da je stupanj pretjerane reakcije ulagača na odluku o Brexitu bio vrlo razočaravajući i potaknuo zabrinutost vezanu uz buduća ulaganja i odabir portfelja. Ključni indeksi volatilnosti bili su u porastu prije donošenja odluke, a na dan referenduma o Brexitu indeksi volatilnosti su izašli iz okvira normalnog raspona. Rezultati upućuju na to da su sudionici na tržištu preusmjerili svoja sredstva u druge sigurnije investicijske opcije zbog efekata Brexita.

Ključne riječi: Brexit, povrat na dionice, iznadprosječni prinos, kumulativni iznadprosječni prinos, implicirana volatilnost 